\title{
ANALISIS ASPEK NASIONALISME PADA FILM 1911 REVOLUTION (辛亥革命)
}

\author{
Nationalism in Film 1911 Revolution (辛亥革命)
}

\author{
Liana Devi Sibarani; Rudiansyah; Julina \\ Fakultas Ilmu Budaya Universitas Sumatera Utara \\ Jalan Universitas No.19, Kampus USU, Medan, Sumatra Utara, 20155 \\ Pos-el : sibaranilianadevi@gmail.com
}

Naskah masuk: 24 Desember 2018, disetujui: 18 Februari 2019, revisi akhir: 30 April 2019

\begin{abstract}
Abstrak
Penelitian ini berjudul Analisis Aspek Nasionalisme pada Film 1911 Revolution (辛亥革命). Latar belakang penelitian ini beranjak dari ketertarikan terhadap karya sastra yang berlatar tentang perjuangan kaum revolusioner untuk mencapai kemerdekaan. Yang menjadi rumusan masalah penelitian ini yaitu apa saja aspek nasionalisme pada film Xinhai Geming. Tujuan penelitian ini adalah mencari, mengungkapkan dan mendeskripsikan rumusan masalah tersebut secara utuh dan terperinci. Metode penelitian yang digunakan dalam penelitian ini adalah metode deskriptif kualitatif. Teori yang digunakan dalam penelitian ini adalah teori sosiologi sastra menurut Wellek dan Warren. Sumber data yang digunakan dalam penelitian ini adalah film Xinhai Geming yang disutradarai oleh Zhang Li dan Jackie Chan yang berdurasi 125 menit dan dirilis oleh Shanghai Film Group pada tanggal 23 September 2011. Hasil dari penelitian ini adalah aspek nasionalisme dan faktor yang mempengaruhi nasionalisme dalam film diwakili oleh beberapa potongan kutipan dan adegan. Nasionalisme yang dimiliki oleh masyarakat Tionghoa adalah pengabdian dan semangat juang untuk membangun rakyatnya demi tercapainya misi bangsa.
\end{abstract}

Kata kunci: nasionalisme, sosiologi sastra, film, Xinhai Geming

\begin{abstract}
This research is entitled Nationalism in Film 1911 Revolution (辛亥革命). The background of this study are an literary work set against the struggle of the revolutionaries to achieve independence. Two things that formulate the research problem are (1) what are the aspects of nationalism in the film Xinhai Geming. The purpose of this research is to find, express and describe the formulations of the problem in a complete and detailed manner. The research method used in this study is a qualitative descriptive method. The theory used in this study is the theory of literary sociology according to Wellek and Warren. The data sources used in this study were the Xinhai Geming film directed by Zhang Li and Jackie Chan which lasted 125 minutes and was released by the Shanghai Film Group on September 23, 2011. The results of this study were aspects of nationalism and factors that influenced nationalism in the film. represented by several quotations and scenes that show nationalism in the film. Nationalism possessed by the Chinese community as devotion and fighting spirit to build its people for the achievement of the nation's mission.
\end{abstract}

Keywords: nationalism, sociology of literature, Xinhai Geming, film

\section{PendahUlUaN}

Karya sastra adalah pengungkapan dari fakta artistik dan imajinatif sebagai manifestasi (perwujudan) kehidupan manusia, melalui bahasa sebagai medium dan memiliki efek yang positif terhadap kehidupan manusia (Esten, 1978:9). Karya sastra merupakan hasil karya manusia baik lisan maupun tulisan yang memiliki estetik (keindahan bahasa) yang dominan. Karya 
sastra dapat memberi kegembiraan dan kepuasan batin dan juga dapat dijadikan sebagai suatu pengalaman untuk berkarya, karena siapapun bisa menuangkan isi hati dan pikiran kedalam sebuah tulisan yang bernilai seni. Karya sastra lahir di tengahtengah masyarakat sebagai hasil imajinasi pengarang serta refleksinya terhadap gejala-gejala sosial yang ada di sekitarnya (Pradopo, 2001:61).

Jenis karya sastra dapat berupa drama, cerpen, atau novel. Namun seiring berjalannya waktu sastra pun semakin berkembang dari yang bersifat tekstual hingga yang bersifat visual hal itu disebabkan karena kemajuan ilmu pengetahuan dan teknologi. Drama, cerpen, novel sekarang sudah dapat dinikmati setelah mengalami perubahan ke bentuk film.

Film merupakan media komunikasi yang bersifat audio visual untuk menyampaikan suatu pesan kepada sekelompok orang yang berkumpul disuatu tempat tertentu (Effendy, 2000:134). Film dibagi menjadi dua unsur yakni, unsur naratif dan unsur sinematik. Dua unsur tersebut saling berinteraksi dan saling berkesinambungan satu sama lain untuk membentuk sebuah film. Dapat dikatakan bahwa unsur naratif adalah bahan (materi, cerita) yang akan diolah, sementara unsur sinematik adalah cara atau aspek pembentukan atau pegolahan film (Prastista, 2008:1).

Film menjelaskan bagaimana cerita dengan menggunakan dialog dan aksi, sehingga mempermudah penonton untuk memahaminya. Umumnya film dijadikan sebagai wahana untuk memberikan hiburan tetapi selain sebagai hiburan, film juga bermanfaat sebagai media pembelajaran. Film dapat dijadikan sebagai pendidikan yang baik dan media visual yang memiliki nilai hiburan, artistik (seni). Film dengan sastra dan bahasa mempunyai hubungan yaitu sama-sama menyampaikan pesan atau memberikan petunjuk kepada sekelompok manusia untuk dapat bekerja sama dan berkomunikasi satu sama lain dengan baik.

Banyak permasalahan hidup yang dapat dijadikan inspirasi oleh pengarang. Kehidupan yang disampaikan dalam karya sastra tidak dapat terlepas dari realitas kehidupan masyarakat, termasuk permasalahan sosial. Nasionalisme merupakan bagian dari permasalahan sosial, karena menyangkut tentang kehidupan masyarakat dalam berbangsa dan bernegara. Masalah nasionalisme sering diangkat dalam cerita baik berbentuk novel maupun film, salah satunya film 辛亥革命 (Xinhai Geming). Oleh karena itu, kajian sosiologi sastra digunakan dalam mengkaji nasionalisme yang terdapat dalam film ini. Sosiologi sastra dapat dipakai untuk mempelajari hubungan atau konflik yang timbul di antara seorang manusia dengan manusia lainnya. Ratna menjelaskan bahwa teoriteori sosiologi yang dapat menopang analisis sosiologi adalah teori-teori yang dapat menjelaskan hakikat fakta-fakta sosial, karya sastra sebagai sistem komunikasi khususnya dalam kaitannya dengan aspek-aspek ekstrinsik seperti: kelompok sosial, kelas sosial, stratifikasi sosial, interaksi sosial, konflik sosial, kesadaran sosial, permasalahan sosial, dan sebagainya (Ratna, 2003: 18).

Film 辛亥革命 (Xinhai Geming) merupakan karya Zhang Li dan Jackie Chan yang menceritakan mengenai kisah perjuangan kaum Nasionalis yang berjuang dari penghapusan kekaisaran dan menggantikannya dengan negara Republik. Pada saat itu Dinasti Qing dipimpin oleh seorang kaisar yang berusia tujuh tahun, dan ibunya yang kejam yaitu Permaisuri Longyu. Dinasti Qing tidak tergoyahkan selama 250 tahun kepemimpinan dinasti tersebut.

Film 辛亥革命 (Xinhai Geming) diproduksi oleh Shanghai Film Group dan dirilis pada 23 September 2011 dengan pemeran utama Jackie Chan dan Winston Chao. Film ini juga menceritakan saat dunia memasuki abad ke-20 yang saat itu negara Tiongkok masih tetap tidak mengalami kemajuan. Rakyat masih tetap hidup di bawah tindasan Dinasti Qing. Setelah sekian lama rakyat akhirnya tidak dapat lagi bersabar. Kesadaran rakyat Tiongkok berawal dari bangkitnya gerakan yang dipelopori oleh Sun Yat Sen. Saat itu juga muncul Huang Xing yang baru saja tiba dari Jepang untuk mempelajari seni perang modern. Saat Huang Xing melihat 
negaranya hancur, ia memutuskan untuk berperang dan memimpin serangkaian pemberontakan. Oleh karena itu, negara ini dibagi menjadi kelompok-kelompok yang bertikai, warga kelaparan, dan reformasi politik yang membuat situasi semakin memburuk.

Berdasarkan gambaran cerita pada film 辛亥革命 (Xinhai Geming), penulis menemukan aspek nasionalisme pada film melalui perjuangan yang diperankan oleh beberapa tokoh dalam film. Ciri nasionalisme pada film ini yaitu adanya cita-cita untuk bebas, keinginan bersama untuk mendapatkan hidup yang lebih baik lagi atau terlepas dari setiap penindasan, dan semangat rela berkorban demi kepentingan bangsa dan negara.

Nasionalisme berasal dari kata nation yang berarti negara atau bangsa, ditambah akhiran -isme yang berarti (a) suatu sikap ingin mendirikan negara bagi bangsanya sesuai dengan paham/ideologinya, (b) suatu sikap ingin membela tanah air/negara dari penguasaan dan penjajahan bangsa asing (Budiyono, 2007:208).. Nasionalisme memunculkan adanya gerakan atau sentimen. Sentimen secara psikologi merupakan bentuk ungkapan marah dan benci. Sentimen ini memunculkan bentuk gerakan penekan. Nasionalisme tidak lahir dengan sendirinya, tetapi lahir dari suatu respon politik, ideologi terhadap peristiwa yang mendahuluinya, yaitu imperialisme. Ernest Renan menyatakan bahwa nasionalisme merupakan unsur yang dominan dalam kehidupan sosial-politik untuk menyatukan kehendak untuk bersatu. Ernest Renan juga menyebutkan bahwa nasionalisme sebagai le desire d'entre ensemble atau kehendak untuk bersatu. Setiap adanya pergerakan dilakukan oleh kelompok yang dijajah guna membebaskan masyarakat dari penjajahan (Dault, 2005:2).

Unsur penting dalam nasionalisme adalah keyakinan dari suatu kelompok masyarakat pada suatu bangsa. Keyakinan tersebut adalah bahwa ketika berhadapan dengan bangsa lain atau orang/sekelompok lain, bangsa itu harus bebas merdeka, memegang hak-haknya dan menikmati kedaulatannya. Nasionalisme bukan hanya tentang mempunyai rasa kesamaan kebudayaan tetapi suatu keinginan atau rasa akan sebuah kemerdekaan serta keselamatan dan kehidupan yang layak bagi masyarakat tanpa ada beban dari pihak manapun yang mendominasi.

Penelitian ini memfokuskan pada aspek nasionalisme dengan analisis sosiologi sastra pada film 辛亥革命 (Xinhai Geming). Penulis tertarik melakukan penelitian terhadap film 辛亥革命 (Xinhai Geming) karena film ini cukup lengkap menggambarkan perjuangan para kaum nasionalis yang berjuang demi sebuah kedamaian dan berjuang dalam menghadapi pemimpin yang kurang tepat. Film ini menunjukkan adanya rasa kebersamaan, keadilan, perdamaian dan kesejahteraan akan kehidupan bersama yang menjadi cita-cita dan harapan bersama. Oleh karena itu, film ini menunjukkan bahwa rasa nasionalisme oleh para kaum pemuda masih dipegang teguh. Kaum pemuda menampilkan karakter intelektual yang netral dan nasionalisme yang konsisten. Adapun yang menjadi tujuan penelitian ini adalah untuk mendeskripsikan aspek nasionalisme yang terdapat pada film 1911 Revolution.

\section{METODE PENELITIAN}

Sosiologi sastra merupakan pengetahuan tentang sifat dan perkembangan masyarakat atau mengenai karya sastra para kritikus dan sejarawan yang terutama mengungkapkan pengarang yang dipengaruhi oleh status lapisan masyarakat tempat ia berasal, ideologi politik dan sosialnya, kondisi ekonomi serta khalayak yang ditujunya (KBBI, 2010). Sosiologi sastra adalah telaah yang objektif dan ilmiah tentang manusia dalam masyarakat (Damono, 1978:6). Sosiologi sastra yang berhubungan dengan masyarakat dalam menciptakan karya sastra tentunya tidak lepas dari pengaruh budaya tempat karya sastra dilahirkan.

Menurut Wellek dan Warren (dalam Damono, 1978:3), hubungan sastra erat kaitannya dengan masyarakat. Sastra adalah ungkapan perasaan masyarakat. Sastra mencerminkan dan mengekspresikan kehidupan pengarang, 
sastra dapat mengekspresikan pengalaman dan pandangan tentang hidup.

Wellek dan Warren (dalam Damono, 1978:3), mengklasifikasikan masalahmasalah sosiologi sastra yang intinya adalah sebagai berikut:

1. Sosiologi pengarang yang mempermasalahkan status politik, ideologi sosial, dan lain-lain yang menyangkut pengarang sebagai penghasil karya sastra tersebut.

2. Sosiologi karya sastra yang mempermasalahkan isi karya itu sendiri, dan yang menjadi pokok penelaahannya adalah hal apa yang tersirat dalam karya sastra tersebut dan apa yang menjadi tujuannya.

3. Sosiologi sastra yang mempermasalahkan pembaca dan pengaruh sosial suatu karya sastra.

Menurut Wellek dan Warren (dalam Damono, 1978 :10), biasanya masalah seputar "sastra dan masyarakat" bersifat sempit dan eksternal. Pernyataan yang ditampilkannya biasanya mengenai hubungan sastra dan situasi sosial tertentu, sistem ekonomi, sosial, dan politik.

Perbedaan yang ada antara sosiologi dan sastra adalah sosiologi melakukan analisis ilmiah yang objektif, sedangkan karya sastra menyusup menembus permukaan kehidupan sosial dan menunjukkan cara-cara manusia mengahayati masyarakat dengan perasaanya (Damono, 1978:8). Masalah pokok sosiologi sastra adalah karya sastra itu sendiri, sebagai aktivitas kreatif dengan ciri yang berbeda-beda (Ratna, 2003:8).

Dalam konteks penelitian ini akan menggunakan pendekatan sosiologi sastra yang berhubungan dengan karya sastra itu sendiri. Penulis akan mengkaji isi karya sastra serta hal-hal yang menjadi permasalahan dalam karya sastra yang berkaitan dengan nasionalisme.

Nasionalisme adalah paham terhadap bangsa dan negara tempat bernaung (Shafer 1955: 6). Adapun beberapa makna nasionalisme menurut Boyd C Shafer, yaitu sebagai berikut.

1. Nasionalisme adalah rasa cinta pada tanah air, ras, bangsa, atau budaya yang sama.
2. Nasionalisme adalah suatu kebaktian mistis terhadap organisme sosial yang kabur, yang kadang-kadang bahkan adikodrati yang disebut sebagai bangsa (sikap kesukarelaan rakyat atau anggota masyarakat kepada pemerintah atau yang dianggap berkuasa).

3. Nasionalisme adalah suatu keinginan akan kemerdekaan politik, keselamatan, dan prestise bangsa.

4. Nasionalisme adalah dogma yang mengajarkan bahwa individu hanya hidup untuk bangsa dan bangsa demi bangsa itu sendiri.

Untuk mengkaji penelitian ini akan digunakan metode deskriptif kualitatif. Penelitian kualitatif adalah penelitian yang bermaksud untuk memahami fenomena apa yang dialami oleh subjek penelitian misalnya perilaku, persepsi, motivasi, tindakan, perkataan, secara holistik, dan dengan cara deskripsi dalam bentuk katakata dan bahasa, pada suatu konteks khusus yang alamiah dan dengan memanfaatkan berbagai metode alamiah (Moleong, 2007:6). Data primer diperoleh dari beberapa scene yang terdapat pada film 1911 Revolution (辛亥革). Data tersebut kemudian diolah melalui tahapan kategorisasi yang dilanjutkan dengan tahapan analisis (Moleong, 2005:6). Data tersebut dapat berupa teks (dialog) maupun suatu perilaku yang terkumpul yang ditunjukkan oleh peran tokoh pada setiap adegan pada film 1911 Revolution ( 辛亥革命). Sedangkan sumber data sekunder yang digunakan penulis dalam penelitian ini berupa dokumen tertulis seperti jurnal, skripsi serta buku-buku yang relevan dengan penelitian.

\section{HASIL DAN PEMBAHASAN}

Berikut ini akan dipaparkan hasil analisis aspek nasionalisme pada film Xinhai Geming. Dalam hasil penelitian ini digunakan teori sosiologi sastra yang membahas tentang pokok-pokok yang menjadi permasalahan dalam film Xinhai Geming. Yang menjadi pokok permasalahan dalam film adalah aspek nasionalisme yang membahas tentang manusia dalam hidup bangsa dan 
bernegara baik segi sosial, politik maupun ekonomi. Sesuai dengan teori Wellek dan Warren, sosiologi sastra mempermasalahkan isi karya sastra itu sendiri yang berhubungan dengan situasi sosial, politik dan ekonomi.

Penulis menggunakan makna nasionalisme Boyd C. Shafer. Nasionalisme adalah paham terhadap bangsa dan negara tempat bernaung. (Adisusilo, 2008: 5-6) beberapa makna nasionalisme yaitu:

\section{Nasionalisme sebagai Rasa Cinta}

Nasionalisme adalah rasa cinta kepada tanah air, ras, bangsa, atau budaya yang sama. Rasa cinta tanah air, ras, dan bangsa merupakan suatu sikap yang mementingkan kebangsaan di atas segalanya. Seseorang yang memiliki rasa nasionalisme tinggi akan lebih memahami dan menghargai nilai-nilai kebangsaan dan semangat kebangsaan yang tinggi. Cinta tanah air mengandung unsur kasih sayang terhadap tanah air, dimana rasa cinta itu menimbulkan keinginan untuk menjaga, melindungi dan membela dari semua ancaman. Dalam film ini penulis menemukan beberapa kutipan yang menunjukkan adanya rasa cinta tanah air, ras dan bangsa yang ditunjukkan oleh tokoh Sun Yat Sen.

Pada bagian film menit ke 00:58:4000:58:58 diceritakan saat Sun Yat Sen sedang berada di Eropa untuk meyakinkan bankir Eropa agar tidak memberikan pinjaman kepada Dinasti Qing. Sun Yat Sen menjawab pertanyaan dari salah satu Bankir Eropa tentang masa depan Cina yang menurut Sun Yat Sen masih memiliki kesempatan untuk hidup lebih baik dengan sumber daya yang melimpah. Hal ini terlihat pada kutipan dialog sebagai berikut.

德国银行代表：看来你对中目的前景很 悲观。

孙中山：不, 恰恰相反我很乐观。一 个新的国家就要诞生。

我们将会有绵延万里的铁路将会有很多的 银行还有蕴藏丰富的矿山。

Bankir Jerman: "Tampaknya Anda cukup pesimis tentang masa depan di Cina"
Sun Yat Sen: "Tidak, saya tidak. Sebaliknya, visi saya tentang Cina baru sangat positif. Saya melihat begitu banyaknya tumpukan sumber daya alam, aku melihat ribuan bank menyediakan modal baru, aku melihat segunung rel kereta api menghubungkan semua komunitas modern".

(Xinhai Geming : 00:58:40-00:58:58)

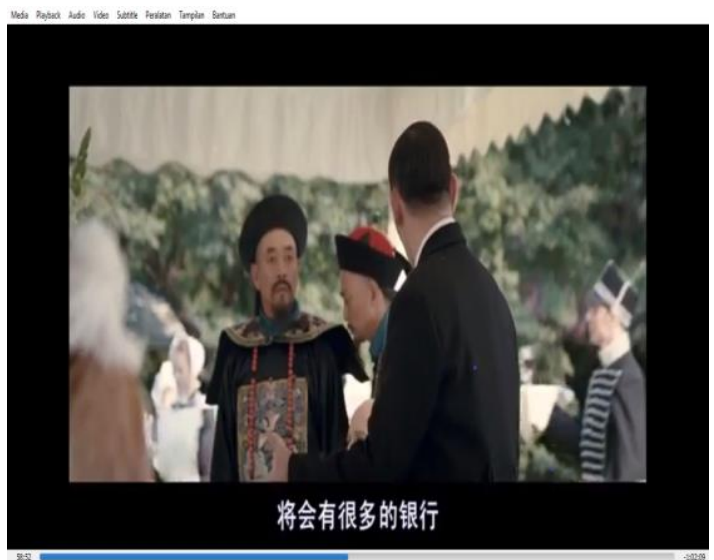

II $m$ เ

Berdasarkan kutipan dialog di atas terlihat bahwa tokoh Sun Yat Sen sedang memuji, kagum dan bangga serta berusaha untuk menjaga nama baik tanah air Cina. Selain itu juga Sun Yat Sen percaya akan masa depan Cina yang lebih baik. Hal ini ditunjukkan pada kutipan "不 恰恰相反我很乐观。一个新的国家就要 诞生。我们将会有绵延万里的铁路将会有很 多的银行还有缊藏丰富的矿山, ” yang berarti "Tidak, saya tidak. Sebaliknya, visi saya tentang Cina baru sangat positif. Saya melihat begitu banyaknya tumpukan sumber daya alam, aku melihat ribuan bank menyediakan modal baru, aku melihat segunung rel kereta api menghubungkan semua komunitas modern".

Pernyataan Sun Yat Sen tersebut dapat dimaknai sebagai salah satu bentuk dari cinta tanah air yaitu memuji atau adanya rasa kebanggaan akan bangsanya sendiri. Melalui kutipan itu juga menunjukkan adanya rasa memiliki dan rasa percaya yang dimiliki oleh Sun Yat Sen pada negaranya yang terlihat dari pernyataannya bahwa ia tidak pesimis akan masa depan Cina. Kekayaan yang dimiliki negara Cina diyakini dapat 
menghasilkan pundi-pundi uang. Walaupun beberapa perwakilan dari setiap bankir Eropa tidak percaya dengan ucapan Sun Yat Sen dan ditambah lagi ucapan dari Menteri Dinasti Qing yang tinggal di luar negeri menyudutkan kaum Revolusioner namun secara perlahan Sun Yat Sen mampu meyakinkan bankir Eropa dengan kepercayaan dirinya dengan memuji dan menaikkan martabat bangsa Cina dihadapan orang luar negeri.

Sesuai dengan pernyataan Wellek dan Warren, scene tersebut mempermasalahkan status politik antara kaum Revolusioner dan Dinasti Qing.

Selanjutnya pada bagian film menit ke 01:54:20-01:54:28 diceritakan saat Sun Yat Sen sudah tidak lagi menjadi presiden, ia mengeluarkan pernyataan tentang revolusi dan kesiapannya untuk melawan serta membela bangsanya dari pemerintahan monarki yang jika suatu saat akan kembali menyengsarakan masyarakat Cina. Hal tersebut terlihat pada kutipan sebagai berikut.

孙中山：革命是让社会进步的理念 从此深入人心。人们懂得了敢有帝制自为者 天下共击之。

Sun Yat Sen : Revolusi memungkinkan sistem Republik untuk mencapai rakyat. Orang-orang akan memahami bahwa kami akan melawan siapapun yang berani mendukung Monarki.

(Xinhai Geming : 01:54:20 - 01:54:28)

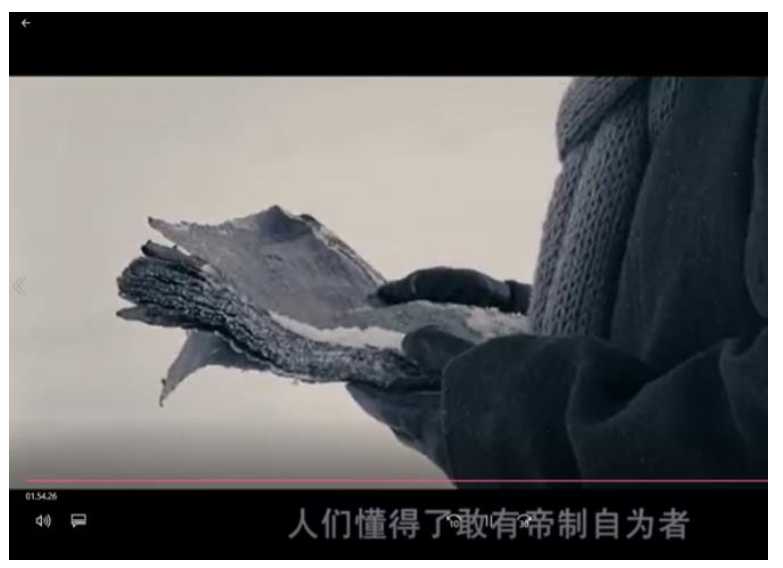

Kutipan dialog di atas menunjukkan kecintaan Sun Yat Sen terhadap bangsa Cina. Cinta tanah air muncul akibat adanya perasaan mencintai dari warga negara untuk negaranya yang sedia mengabdi, melindungi tanah airnya dari segala ancaman, gangguan. Kecintaan Sun Yat Sen didukung oleh kata melawan. Bahwa ia akan siap melawan orang yang mendukung sistem monarki. Sistem monarki memberikan kesengsaraan, tidak adanya kedamaian serta kehidupan yang layak bagi masyarakat. Kata melawan tersebut dapat dimaknai sebagai rasa cinta tanah air dari Sun Yat Sen yang menimbulkan keinginannya untuk menjaga dan membela Cina dari setiap ancaman dan merawat serta melindungi apa yang menjadi hak milik Cina. Dalam hal ini wujud cinta tanah air dari Sun Yat Sen merupakan salah satu cara membantu mewujudkan kedamaian bangsanya sendiri.

\section{Nasionalisme sebagai Kebaktian Mistis}

Nasionalisme adalah suatu kebaktian mistis terhadap organisme sosial yang kabur, yang kadang-kadang bahkan adikodrati yang disebut sebagai bangsa. Menurut Boyd C. Shafer (dalam Adisusilo, 2008:7) penafsiran mengenai makna nasionalisme ini adalah sikap kesukarelaan rakyat atau anggota masyarakat kepada pemerintah atau yang dianggap berkuasa dalam menyukseskan dan meraih cita-cita bangsa. Bentuk sukarela ini dapat berupa ikut serta dalam perjuangan yang dapat mengorbankan nyawa maupun harta.

Pada bagian film menit ke 00:01:4800:02:00 diceritakan ketika Qiu Jin anggota revolusioner perempuan yang akan menjalani hukuman mati karena dianggap pemberontak atau seorang pengkhianat oleh Dinasti Qing. Qiu jin adalah perempuan pertama yang akan menjalani hukuman mati demi revolusi. Hukuman yang akan dijalankannya termasuk bentuk kesukarelaannya sebagai anggota revolusioner. Hal tersebut terlihat pada kutipan sebagai berikut:

秋瑾 : 我此番赴死是为革命。中国 $f$ 妇 女还没有为革命流过血。当从我秋瑾 始。 纵使世人并不尽知革命为何。竟让我狠心抛 弃子。

Qiu Jin: Kematianku adalah demi revolusi. Perempuan Cina masih belum pernah menumpahkan darah demi revolusi. Jadi dimulai dari kematianku. Meskipun 
harus mati juga tidak mengerti untuk apa demi revolusi. Meskipun saya begitu kejam meninggalkan keluarga dan anak-anak". (Xinhai Geming: 00:01:48 - 00:02:00)

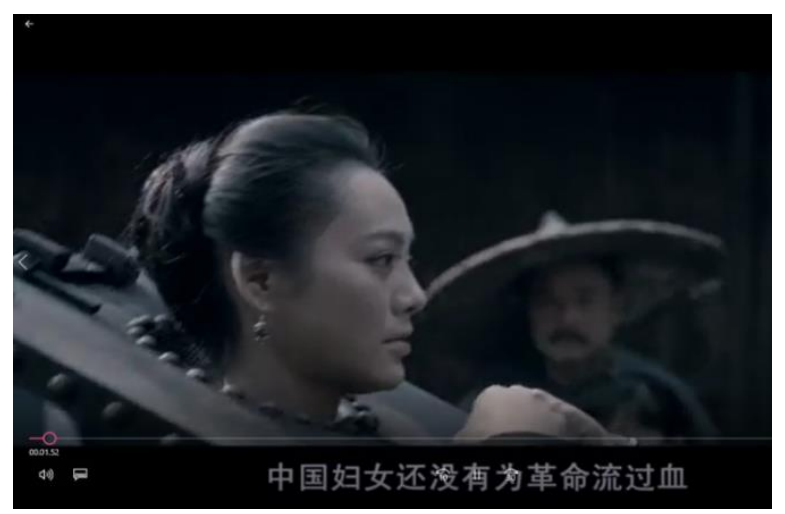

Berdasarkan kutipan dialog di atas terlihat bahwa adanya rasa kesukarelaan seorang wanita yang bernama Qiu Jin (kaum Revolusioner) demi tercapainya kehidupan yang lebih damai. Hal ini dapat terlihat pada dialog "我此番赴死是为革命” yang berarti 'kematianku adalah demi revolusi'. Qiu Jin melalui kerelaannya dihukum mati mencerminkan pengorbanan untuk dapat meraih cita-cita bangsa yaitu untuk mengembalikan martabat bangsa, memberikan kembali keluarga yang layak serta kedamaian. Di balik kerelaannya ada yang harus dikorbankan yaitu keluarga, ia bersedia meninggalkan kedua anaknya. Qiu Jin melakukan perbuatan mulia bukan berarti tanpa rasa takut tetapi ia harus melakukan pengorbanan demi kebahagiaan dan kedamaian orang banyak. Dengan demikian dapat dijelaskan tindakan Qiu Jin yang tergabung menjadi anggota revolusioner menunjukkan rasa nasionalisme terhadap bangsa Cina. Sebagai anggota revolusioner, Qiu Jin bermaksud untuk ikut melakukan perlawanan terhadap Dinasti Qing namun hal tersebut diketahui oleh Dinasti Qing dan akhirnya harus dihukum mati. Dengan cara itulah ia ingin membela serta mengembalikan bangsanya yang telah dirusak oleh kekuasaan Dinasti Qing.

Selanjutnya, pada bagian film menit ke 00:17:34 - 00:17:40 diceritakan ketika Sun Yat Sen selesai memberikan pidato di hadapan orang Cina di San Fransisco, Situ Meitang menemui Sun Yat Sen dan memberikan sejumlah uang untuk membantu revolusi. Situ Meitang memberikan bantuan hasil penjualan rumah leluhurnya. Rumah tersebut merupakan harta satu-satunya yang ia miliki di Cina. Hal tersebut dapat dilihat pada dialog sebagai berikut:

司徒美堂：这三十万美金是我致公堂的 捐赠。不瞒你逸仙, 这是我致公堂变 卖组祖 屋换来的。

Situ Meitang: Ini 30.000 US Dolar adalah harta saya yang terakhir. Sejujurnya, uang ini diperoleh dari hasil menjual rumah leluhur.

(Xinhai Geming : 00:17:34 - 00:17:40)

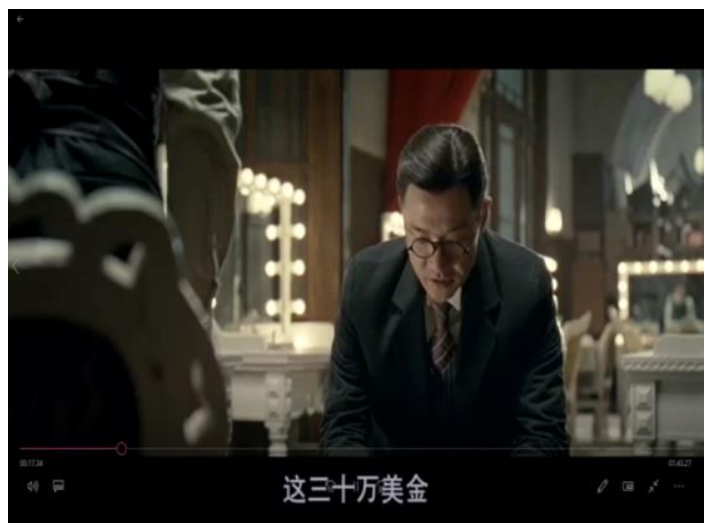

Berdasarkan kutipan dialog di atas terlihat bahwa adanya kerelaan Situ meitang memberikan bantuan sejumlah uang demi keberhasilan revolusi, demi terciptanya Cina yang damai. Adanya harapan yang diberikan Situ Meitang kepada Sun Yat Sen untuk menyukseskan revolusi. Hal itu dapat terlihat pada kutipan “这三十万美金是我致公堂的捐赠。不瞒你 逸仙, 这是我致公堂变卖组祖屋换来的" yang berarti "Ini 30.000 US dolar adalah harta saya yang terakhir. Sejujurnya, uang ini diperoleh dari hasil menjual rumah leluhur". Kutipan tersebut dapat dimaknai bahwa adanya pengorbanan Situ Meitang untuk keberhasilan revolusi melalui sejumlah uang yang ia berikan kepada Sun Yat Sen. Uang itu merupakan hasil penjualan satu-satunya rumah leluhur yang tersisa. Situ Meitang mengorbankan rumahnya demi tercapainya cita-cita revolusi. Karena saat itu kaum Revolusioner sedang membutuhkan dana untuk memperkuat kekuasaan mereka melawan Dinasti Qing. Bentuk pengorbanan bukan hanya berupa nyawa, 
pikiran, perasaan tetapi juga berupa harta benda. Pengorbanan Situ Meitang memberikan uangnya bersifat kebaktian yang tidak mengandung pamrih melainkan didasarkan atas kesadaran moral yang tulus ikhlas.

\section{Nasionalisme sebagai Cita-Cita Merdeka}

Nasionalisme adalah suatu keinginan akan kemerdekaan politik dan keselamatan. Keinginan akan kemerdekaan dan keselamatan merupakan kesempatan untuk membangun bangsa menjadi lebih baik, dapat terbebas dari penjajah. Bebas dari penjajahan merupakan hal yang sangat penting. Itu merupakan penegasan untuk berhak menentukan nasib negara, tidak ada yang mengatur tidak ada yang menggangu hak untuk hidup bahagia.

Pada bagian film menit ke 00:02:0800:02:17, diceritakan ketika Qiu Jin akan melakukan hukuman mati. Qiu jin menjelaskan keinginannya untuk Cina yang lebih damai melalui kematiannya. Melalui pengorbanannya tersebut dia berharap revolusi dapat tercapai agar kehidupan masyarakat di Cina kembali damai, bahagia tanpa penindasan dari pemerintahan yang monarki. Qiu Jin berharap revolusi dapat berjalan dengan sukses agar dapat membangun kembali negara yang telah dirusak oleh Dinasti Qing. Hal tersebut dapat terlihat pada kutipan sebagai berikut:

秋瑾: 我此 番赴死正为回答革命所为何 事。革命是为给天下人造一个风雨不侵的家 。给孩子一个宁静温和的世界。

Qiu Jin : Kematianku bukti untuk menjawab pertanyaan untuk apa melakukan revolusi. Revolusi untuk rakyat dunia agar bisa membangun kembali keluarga yang layak bagi mereka, memberikan anak-anak dunia yang damai dan kehangatan."

(Xinhai Geming : 00:02:08-00:02:17)

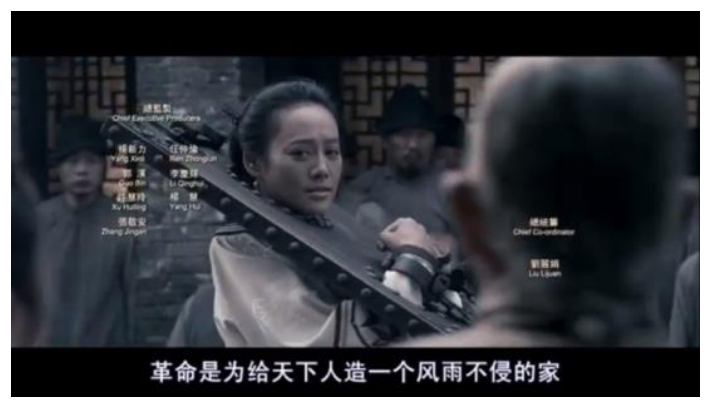

Kutipan dialog di atas menunjukkan adanya keinginan akan kemerdekaan atau keselamatan dari Qiu Jin terhadap bangsa Cina. Ia berharap melalui kematiannya akan menciptakan kemerdekaan serta keselamatan dan kehidupan yang layak bagi Bangsa Cina. Hal tersebut dapat terlihat dari kutipan, "革命是为给天下人造 一个风雨不侵的家。给孩子一个宁静温和 的世" yang berarti "revolusi untuk rakyat dunia agar bisa membangun kembali keluarga yang layak bagi mereka, memberikan anak-anak dunia yang damai dan kehangatan." Dapat dimaknai bahwa melalui kematiannya, Qiu Jin ingin adanya perubahan bagi rakyat Cina. Pengorbanan yang dilakukan Qiu Jin bukanlah rasa tanpa takut tetapi karena keinginannya untuk menyelamatkan masyarakat Cina. Qiu Jin berkorban nyawa demi kebahagiaan dan ia juga sadar bahwa setiap manusia memiliki hak untuk selamat, terbebas dari penjajah sehingga ia melakukan pengorbanan nyawa. Ia berharap melalui kematiannya masyarakat Cina bisa mendapatkan kembali kehidupan yang layak yang damai serta keselamatan. Keinginan Qiu Jin hanya untuk terbebas dari belenggu, kekuasaan dan aturan penjajah. Jika Revolusi berhasil maka dapat dinikmati rasa kebebasan untuk mendapatkan hak dalam melakukan sesuatu di negara sendiri.

Selanjutnya, Pada bagian film menit ke 00:30:24-00:30:30 diceritakan ketika Sun Yat Sen sedang berada di San Fransisco tepatnya di kediaman Homer Lee. Saat itu Homer Lee penasaran tentang revolusi Cina kemudian Sun Yat Sen menjelaskan dan dengan tegas mengatakan kesiapannya untuk mengubah Cina menjadi negara yang damai. Hal tersebut terlihat pada kutipan sebagai berikut: 
孙中山: 现在, 我不接受, 我不承认, 我不同意, 我要改变, 我要革命。

Sun Yat Sen : Sekarang aku tidak bisa menerimanya. Saya ingin mengubahnya, saya ingin sebuah revolusi".

(Xinhai Geming : 00:30:24-00:30:30)

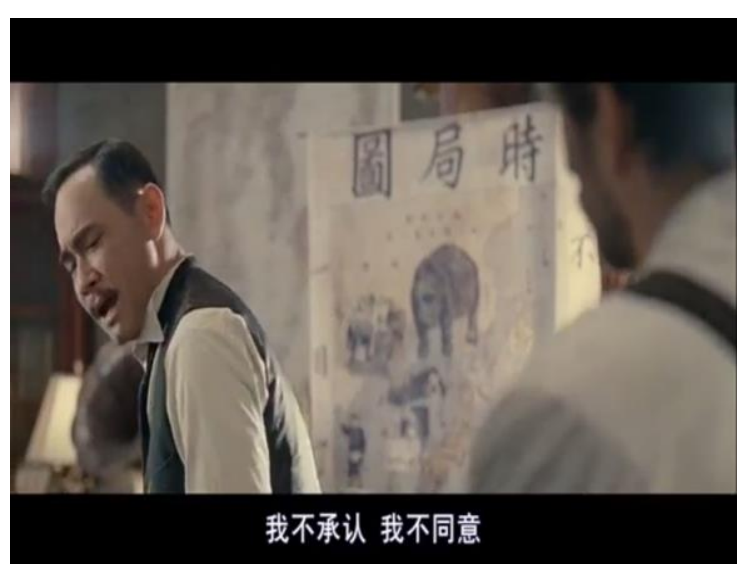

Kutipan dialog di atas bermakna bahwa Sun Yat Sen ingin adanya suatu perubahan, tidak adanya kesengsaraan tetapi yang ada kedamaian, keselamatan melalui revolusi. Sun Yat Sen tidak sabar lagi melihat bangsanya menderita di bawah ancaman imperialisme asing dan feodalisme kerajaan yang pada saat itu juga negara Cina sedang berada di ambang perpecahan. Hal ini dapat dilihat dari kutipan "现在, 我不接受, 我不承认, 我不同意, 我要改变, 我要革命" yang berarti "Sekarang aku tidak bisa menerimanya. Saya ingin mengubahnya, saya ingin sebuah revolusi". Sun Yat Sen dengan tegas mengatakan ketidaksabarannya dengan pemerintahan Dinasti Qing sekaligus menginginkan revolusi Cina. Sun Yat Sen menujukkan keinginannya untuk mengubah nasib masyarakat Cina yang telah lama ditindas oleh Dinasti Qing sehingga ia melakukan berbagai cara untuk melawan dan meruntuhkan kekuasaan Dinasti Qing. Hal ini terlihat sisi nasionalisme sangat melekat pada tokoh Sun Yat Sen yang ingin adanya suatu kemerdekaan dan perubahan dalam bangsanya.

\section{Nasionalisme sebagai Dogma}

Nasionalisme adalah dogma yang mengajarkan bahwa individu hanya hidup untuk bangsa. Pada bagian film menit ke 00:15:20-00:15:39 terlihat ketika Sun Yat
Sen melalukan pidato di luar negeri di depan orang Cina yang berada di luar negeri. Sun Yat Sen menyatakakan tentang bentuk pengabdian para pemuda yang meninggal saat ikut dalam aksi pemberontakan. Mereka tidak takut akan bahaya dan tidak menghargai keluarga yang telah mereka tinggal. Mereka begitu berani semua itu hanya karena sebuah kata kepercayaan. Pidato Sun Yat Sen itu untuk menumbuhkan rasa kesadaran untuk mengerti tujuan dibalik sebuah revolusi yaitu untuk kebahagiaan dan mendapatkan kembali martabat bagi bangsa Cina.

\section{孙中山 : 这些死去的年轻人有的才} 华横溢。有的家境优越。有的新婚燕 尔。他们何以不惜身家性命, 不计成败利害 。甘死如饴。只因信仰二字。

Sun Yat Sen : Para pemuda yang meninggal ada yang memiliki bakat yang besar. Ada yang memiliki keluarga yang baik. Ada yang baru saja menikah. Mereka mengapa tidak menghargai keluarga mereka? Tidak peduli bahaya. Begitu berani berkorban. Mereka rela berkorban hanya karena sebuah kata kepercayaan".

(Xinhai Geming : 00:15:20-00:15:39)

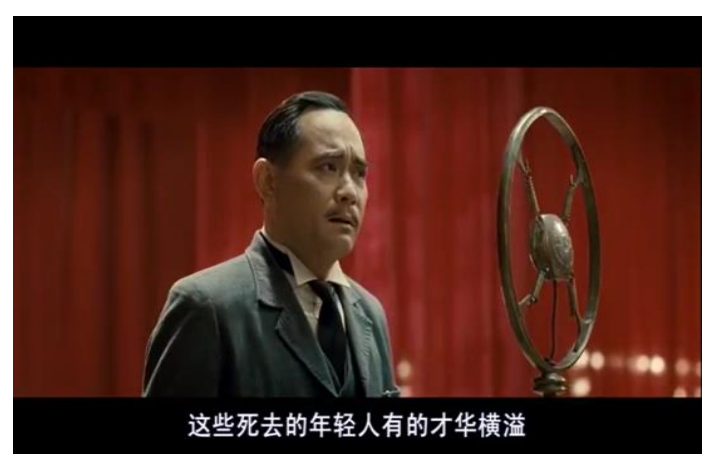

Kutipan dialog di atas menunjukkan bahwa Sun Yat Sen berusaha meyakinkan masyarakat Cina untuk sadar bahwa mereka hidup di bawah penindasan Dinasti Qing dan para pemuda sedang berjuang untuk meruntuhkan kekuasaan Dinasti Qing. Sun Yat Sen menyatakakan bahwa bentuk pengabdian para pemuda yang meninggal saat ikut dalam aksi pemberontakan tidak takut akan bahaya dan tidak menghargai keluarga mereka yang ditinggal. Hal tersebut terlihat pada kalimat kutipan "这些死去的年轻人有的才 华横溢。有的家境优越。有的新婚燕尔。他 
们何以不惜身家性命, 不计成败利害。甘死 如饴。只因信仰二字" yang berarti "Para pemuda yang meninggal ada yang memiliki bakat yang besar. Ada yang memiliki keluarga yang baik. Ada yang baru saja menikah. Mereka mengapa tidak menghargai keluarga mereka? Tidak peduli bahaya. Begitu berani berkorban. Mereka rela berkorban hanya karena sebuah kata kepercayaan".

Kutipan tersebut dapat dimaknai bahwa para pemuda berjuang hanya demi keberadaan yaitu Negara Cina sendiri. Perbuatan tanpa pamrih yang dilakukan oleh pemuda yang tergabung pada revolusioner menunjukkan bahwa mereka menempatkan kepentingan bangsa dan negara di atas kepentingan pribadi dan golongan. Mereka bahkan tetap bertahan dan rela mati dalam pemberontakan, lalu meninggalkan keluarga untuk ikut melakukan pemberontakan. Sikap para pemuda ini mencerminkan sikap seorang pahlawan sejati yang tidak takut mati dan tidak takut bahaya. Pahlawan sejati akan berjuang demi bangsa dan negara tanpa mengharapkan imbalan. Bentuk nasionalisme pada data ini ditunjukkan oleh perjuangan kaum pemuda yang berjuang demi bangsanya tetapi disampaikan oleh Sun Yat Sen sebagai salah satu cara untuk memberikan kesadaran terhadap masyarakat Cina yang minim akan kepeduliaan sesama.

Selanjutnya pada bagian film menit ke 1:32:27-1:32:34 diceritakan ketika Sun Yat Sen membacakan janji setalah terpilih menjadi seorang Presiden. Salah satu isi janjinya yaitu berjanji akan melayani negara sampai hegemoni Dinasti Qing tumbang. Hal tersebut terlihat pada kutipan sebagai berikut:

孙中山：此国民之公意文实遵之以忠于 国为众服务至专制政府既到国内无变乱。

Sun Yat Sen : Ini aku berjanji kepada orang-orang. Aku akan mengikuti mereka. Aku akan melayani negara dengan Iman, aku akan melayani semua orang sampai hegemoni Dinasti Qing ditumbangkan.

(Xinhai Geming : 1:32:27-1:32:34)

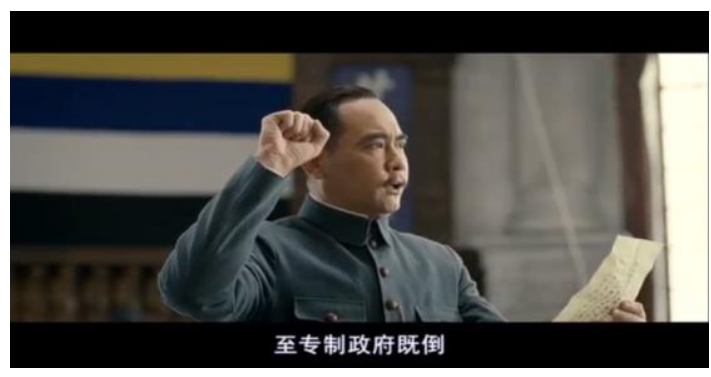

BKkutipan dialog di atas dapat dimaknai bahwa bentuk nasionalisme dari Sun Yat Sen yang ditandai pada kutipan " 此国民之公意文实遵之以忠于国为众服务至 专制政府既到国内无变乱"yang berarti "Ini aku berjanji kepada orang-orang. Aku akan mengikuti mereka. Aku akan melayani negara dengan Iman, aku akan melayani semua orang sampai hegemoni Dinasti Qing ditumbangkan". Kutipan tersebut dapat dimaknai bahwa Sun Yat Sen akan lebih mementingkan kehidupan bangsa dan masyarakatnya. Melalui janjinya tersebut ia akan siap melayani negara dan berjuang sampai Dinasti Qing mundur. Sun Yat Sen jelas menunjukkan nasionalismenya sebagai masyarakat bahwa ia hidup, mati dan berjuang untuk bangsanya agar menjadi bangsa yang damai. Sun Yat Sen bersedia mempertahakan dan turut memajukan Negara serta menjaga nama baik bangsanya.

\section{SIMPULAN}

Setelah menganalisis film Xinhai Geming dapat ditarik simpulan bagaimana aspek nasionalisme serta faktor-faktor apa saja yang mempengaruhi nasionalisme. Terdapat empat aspek nasionalisme dalam kajian aspek nasionalisme film Xinhai Geming ini. Keempat aspek nasionalisme tersebut menggunakan teori nasionalisme Adisusilo, yaitu (a) rasa cinta pada tanah air, ras, bangsa, atau budaya yang sama. Pada film ini cinta tanah air ditunjukkan dengan cara memuji bangsa, menjaga bangsa dengan melakukan perlawan terhadap sesuatu yang mengganggu bangsa sendiri (b) Sikap kesukarelaan rakyat atau anggota masyarakat kepada pemerintah atau yang dianggap berkuasa. Bentuk kesukarelaan yang terdapat pada film ini yaitu Qiu Jin kemudian Situ Meitang mengorbankan harta benda yang 
dimilikinya. (c) Keinginan akan kemerdekaan politik, keselamatan. Keinginan tersebut dijelaskan oleh Qiu Jin ketika akan dihukum mati Qiu Jin berharap akan cina yang lebih baik, kemudian Sun Yat Sen yang ingin meruntuhkan Dinasti Qing dan menyukseskan revolusi. (d) Mengajarkan bahwa individu hanya hidup untuk bangsa dan bangsa demi bangsa itu sendiri.

Semua aspek nasionalisme ini timbul dengan sendirinya pada saat Sun Yat Sen dan tokoh revolusioner lainnya menjalani perjuangan untuk revolusi Cina. Tokoh yang paling banyak menunjukkan nasionalismenya adalah Sun Yat Sen sebagai pelopor pendirinya Revolusioner
(Tongmenghua). Kehadiran Sun Yat Sen disetiap scene menjadi tanda bahwa Sun Yat Sen adalah tokoh yang menjadi pemeran utama dalam film.

Sebagai saran, penelitian mengenai film Xinhai Geming ini masih perlu diteliti lebih lanjut karena film ini mengandung nilai perjuangan, patriotisme yang tinggi. Dalam penelitian ini hanya terbatas pada aspek nasionalisme oleh karena itu nilai perjuangan dan bentuk nasionalisme dalam flm ini sangat menarik untuk diteliti selanjutnya. Dan diharapkan tulisan ini dapat memberikan kontribusi dalam menelaah karya sastra, khususnya dalam kajian film.

\section{DAFTAR PUSTAKA}

Adisusilo, Sutarjo. (2008). Nasionalisme-Demokrasi-Civil Society. Yogyakarta: Universitas Sanata Dharma.

Aminuddin. (2000). Pengantar Apresiasi Karya Sastra. Bandung: Sinar Baru Algensindo.

Budiyono, K. (2007). Nilai-Nilai Kepribadian dan Kejuangan Bangsa Indonesia. Bandung: Alfabeta.

Damono, Sapardi Djoko. (1978). Sosiologi Sastra Sebuah Pengantar Ringkas. Jakarta: Departemen Pendidikan dan Kebudayaan.

Dault, Adhyaksa. (2005). Islam dan Nasionalisme: Reposisi Wacana Universal dalam Konteks Nasional. Jakarta: Pustaka Al-Kautsar.

Effendy, Onong Uchjana. (2000). Mari Membuat Film, Panduan untuk Menjadi Produser, (Panduan \& Pustaka Konfiden). Yogyakarta:Pustaka Pelajar.

Esten, Mursal. (1978). Kesusastraan: Pengantar Teori dan Sejarah. Bandung: PT Angkasa.

Ichwan, Yasir. (2014). "Nasionalisme dalam Novel $5 \mathrm{~cm}$ Karya Donny Dhirgantoro: Analisis Strukturalisme," Skripsi. Medan: Universitas Sumatera Utara.

Liliweri, Alo. (1991). Komunikasi Antar Personal. Bandung: Citra Aditya Bakti.

Moleong. (1989). Metodologi Penelitian Kualitatif. Bandung: Remaja Rosdakarya.

Muin, Asrhawi. (2015). "Nilai Nasionalisme dalam Film Tanah Surga Katanya (Analisis Semiotika)," Skripsi. Makassar: Universitas Hasanuddin.

Pratista, Himawan. (2008). Memahami Film. Yogyakarta: Homerian Pustaka

Pradopo, Rachmat Djoko. (2001). Kritik Sastra Modern. Yogyakarta: Gama Media. 
Rudiansyah: Analisis Aspek Nasionalisme pada Film 1911 Revolution

Ratna, Kutha. (2003). Teori, Metode, dan Teknik Penelitian Sastra. Yogyakarta: Pustaka Pelajar. 